\title{
ANALISIS KOMPETENSI PELAKU USAHA, PERAN DAN KEBIJAKAN PEMERINTAH TERHADAP KINERJA UKM DI KOTA TANGERANG DENGAN KREATIVITAS STRATEGI PEMASARAN SEBAGAI VARIABEL INTERVENING
}

Sugeng Lubar Prastowo

Fakultas Ekonomi dan Bisnis

Universitas Islam Syekh-Yusuf, Tangerang

slubar@unis.ac.id

https://doi.org/10.33592/jeb.v25i2.435

\section{Abstract}

The analysis of the competence of business actors, as well as the roles and policies of the Tangerang city government on the performance of SMEs in the city of Tangerang with the creativity of the marketing strategy as an intervening variable, is the result of a study of SMEs and owners who live and run their businesses in the Tangerang City area. Growth and improvement in the performance of SMEs play an important role in improving people's welfare, regional income and improving the national economy. The number of SMEs in the city of Tangerang continues to increase every year, but this increase is still less accelerated compared to the growth of SMEs in South Tangerang, while the area of the city of Tangerang has the potential for strategic economic movement as a city that has international airport facilities and as an economic route connecting activities industry and business. The research method uses quantitative methods associative type by looking for cause and effect relationships, the object of research in the population of SMEs in the city of Tangerang with 200 respondents of SME owners. Data collection techniques with secondary data and primary data through Likert scale questionnaires. Statistical analysis techniques use path analysis with the SPSS program to examine the relationship between variables. From the results of the study show that the business competency variables, role variables and government policies, and marketing strategy creativity, directly have a significant positive effect on improving the performance of SMEs in Tangerang City. To increase creativity a good marketing strategy is also directly influenced by the competence of business actors.

Keywords: UKM, Competence, Strategy, Marketing, Performance.

\section{Abstrak}

Analisis kompetensi pelaku usaha, serta peran dan kebijakan pemerintah kota Tangerang terhadap kinerja UKM di kota Tangerang dengan kreativitas strategi pemasaran sebagai variabel intervening, adalah hasil penelitian terhadap para pelaku dan pemilik UKM yang berdomisili dan menjalankan usahanya di wilayah kota Tangerang. Pertumbuhan dan peningkatan kinerja UKM berperan penting dalam meningkatan kesejahteraan masyarakat, pendapatan daerah dan peningkatan ekonomi nasional. Jumlah pelaku UKM di kota Tangerang terus mengalami peningkatan setiap tahunnya, tetapi peningkatan ini masih kalah percepatannya dibandingkan dengan pertumbuhan UKM di Tangerang Selatan, sementara wilayah kota Tangerang memiliki potensi pergerakan ekonomi yang strategis sebagai kota yang memiliki fasilitas bandara Internasional dan sebagai jalur ekonomi yang menghubungkan kegiatan industri dan bisnis. Metode penelitian menggunakan metode kuantitatif jenis asosiatif dengan mencari hubungan sebab akibat, obyek penelitian pada populasi pelaku UKM di kota Tangerang dengan responden sebanyak 200 orang pemilik UKM. Teknik pengambilan data dengan data sekunder dan data primer melalui pembagian kuesioner berskala likert. Teknik analisis statistik menggunakan analisis jalur dengan program SPSS untuk menguji hubungan antara variabel. Dari hasil penelitian menunjukkan bahwa variabel kompetensi pelaku usaha, variabel peran dan kebijakan pemerintah, dan kreativitas strategi pemasaran, secara langsung memiliki pengaruh positif secara signifikan terhadap peningkatan kinerja UKM di kota Tangerang. Untuk meningkatkan kreativitas strategi pemasaran yang baik juga dipengaruhi secara langsung oleh kompetensi pelaku usaha.

Kata kunci: UKM, Kompetensi, Strategi, Pemasaran, Kinerja. 


\section{A. Pendahuluan}

\section{Latar Belakang}

Usaha Kecil Menengah (UKM) berperan penting dalam memajukan kesejahteraan ekonomi suatu daerah, bahkan sangat berpengaruh untuk memajukan ekonomi nasional, kemajuan ekonomi nasional dapat dibuktikan dengan angka Produk Domestik Bruto (PDB). Semakin meningkatnya angka pertumbuhan UKM di Indonesia maka ekonomi Indonesia akan mengalami peningkatan. Ketika terjadi masa krisis keuangan (moneter) pada tahun 1997, sektor UKM memberikan pengaruh yang besar pada pertahanan ekonomi Indonesia pada saat itu, di mana banyak perusahaan besar mengalami krisis, tetapi Indonesia masih bisa tetap bertahan, karena adanya daya dukung kekuatan UKM pada saat itu.

Dengan semakin banyaknya muncul pelaku UKM baru, maka dapat membuka kesempatan lapangan pekerjaan baru, yang dapat menyerap tenaga kerja produktif, sehingga mengurangi angka pengangguran. UKM berkontribusi terhadap pendapatan daerah maupun tingkat nasional. Bertumbuhnya angka UKM di suatu daerah, akan memberikan kontribusi positif terhadap kesejahteraan ekonomi rakyat (Susila, 2017).

Pada saat ini, pertumbuhan UKM dan kinerja UKM di masing-masing daerah masih dirasa cukup lemah, sehingga tidak sedikit adanya UKM yang tidak mampu lagi untuk bertahan di era persaingan yang semakin ketat, akibat pengaruh globalisasi ekonomi dari revolusi industri 4.0.

Pertumbuhan dan peranan kinerja UKM di suatu daerah dan suatu negara, dapat ditunjukkan dengan jumlah pertumbuhan unit usaha dan jumlah pengusaha, serta besarnya kontribusi terhadap pendapatan nasional, dan penyediaan lapangan kerja baru (Susila, 2017).

Menurut Kepala Seksi Bina Usaha dan Peningkatan Daya Saing UKM kota Tangerang, pada tahun 2017 di tri wulan pertama, total UKM di kota Tangerang mengalami peningkatan 553 UKM baru. Di mana pada tahun 2016 jumlah UKM yang tercatat pada saat itu sebanyak 10.000 unit, sehingga jumlah total UKM mencapai 10.553 (Irfan, 2017). Saat ini, jumlah pelaku UKM kota Tangerang, terus mengalami peningkatan mencapai 11.000 lebih, diantaranya adalah usaha kuliner dan fashion (Pemkot, 2017). Pemerintah Kota Tangerang terus berupaya meningkatkan pertumbuhan dan memajukan UKM, diantaranya dengan menfasilitasi lokasi kepada para pelaku UKM, untuk memasarkan produkproduknya, seperti di area kuliner di 
kawasan Bandara Internasional SoekarnoHatta, pusat-pusat perbelanjaan, di kawasan taman kota di kota Tangerang (Syarif, 2017).

\section{Identifikasi Masalah}

Apabila UKM di kota Tangerang dibandingkan dengan pertumbuhan UKM di Tangerang Selatan, UKM di Tangerang Selatan bertumbuh dan berkembang lebih pesat dibandingkan pertumbuhan UKM di kota Tangerang. Menurut Dahlia Nadeak, sebagai Plt. Dinas Koperasi dan Usaha Kecil Menengah (UKM) Tangerang Selatan, saat ini Tangerang Selatan memiliki 26.700 UKM yang didominasi usaha kuliner dan fashion (Setiawan, 2018).

Winarni (2006) mengidentifikasikan bahwa permasalahan UKM adalah karena kurangnya modal pelaku UKM, kesulitan dalam pemasaran produk UKM, ketatnya persaingan usaha, kesulitan memperoleh bahan baku, kurangnya kemampuan dan keahlian teknis produksi, kurangnya kompetensi pengelolaan keuangan usaha, dan adanya birokrasi perijinan serta perundang-undangan usaha yang kurang kondusif (Hadiwidjaja \& Hartati, 2013).

Menurut Hadiyati (2009), berdasarkan survey BPS, kelemahan dan masalah-masalah UKM apabila dilihat dari skala prioritasnya, yaitu diantaranya: kurangnya modal, sulit dalam pemasaran, adanya persaingan usaha yang semakin ketat, kesulitan dalam memperoleh bahan baku, kurang adanya kompetensi atau kemampuan teknis produksi dan keahlian, kurangnya managerial skill (SDM) serta kurangnya penguasaan manajemen keuangan dan akuntansi (Purwidianti \& Rahayu, 2015)

Dari data pertumbuhan UKM kota Tangerang apabila dibandingkan dengan pertumbuhan UKM di Tangerang Selatan, maka kedua wilayah UKM sama-sama mengalami kenaikan pertumbuhan, hanya pertumbuhan UKM di wilayah kota Tangerang lebih lambat bila dibandingkan dengan UKM di wilayah Tangerang Selatan. Hal ini menjadi kajian yang menarik, karena potensi wilayah kota Tangerang begitu strategis dimana merupakan jalur lintas distribusi logistik dan produk pemasaran dari beberapa Industri, selain itu wilayah kota Tangerang memiliki bandara Internasional yang berpotensi untuk mengembangkan pemasaran produk ekonomi keratif dari pelaku UKM.

Menurut kepala bidang Usaha Mikro Kecil dan Menengah (UMKM) Dinas Koperasi dan UKM Kota Tangerang, modal usaha merupakan masalah utama para pelaku UKM di kota Tangerang. Masalah-masalah UKM di kota Tangerang sebagaimana permasalahan permodalan 
dapat diberikan solusi dengan program PNPM, termasuk Kredit Usaha Rakyat, diberikan pembinaan usaha, dan pelatihan usaha, sehingga para pelaku UKM dapat bertumbuh dan berkembang dengan baik.

Dasar Permasalahan UKM di Indonesia adalah kemampuan meningkatkan kapasitas usaha. Permasalahan tersebut disebabkan dari dua factor utama, yaitu adanya faktor internal dan faktor eksernal. Permasalahan faktor internal di antaranya kualitas manusia, aspek teknis dan kemampuan operasional, penguasaan pada strategi berbisnis atau pemasaran. Sedangkan faktor eksternal dipengaruhi oleh aspek peran dan kebijakan pemerintah, iklim usaha, serta kondisi stabilitas perekonomian, dan pengaruh persaingan ekonomi global (Susila, 2017).

\section{Kajian Teori}

\section{Kompetensi Pelaku Usaha}

Kompetensi pelaku usaha dapat diartikan sebagai kemampuan kerja pelaku usaha yang dilihat dari aspek pengetahuan, keterampilan, dan kemampuan kerja sesuai yang diharapkan, sehingga memiliki daya tawar dan keunggulan bersaing. Jadi inti dari kompetensi adalah kapasitas knowledge, skill, ability serta attitude yang relevan dengan bidang usahanya sehingga mampu mengaktualisasikan pekerjaannya (Sidharta \& Lusiana, 2014).
Kompetensi merupakan kekuatan potensi sumber daya manusia yang memiliki pengaruh besar terhadap kinerja usaha, hal ini tentu berkaitan erat dengan keahlian dalam bidang pekerjaannya, karena pekerjaan tertentu memiliki standar kompetensi yang telah ditetapkan untuk meningkatkan kinerja usaha (Sidharta \& Lusiana, 2014).

Kompetensi secara intelektual membuat diri individu memiliki motivasi kerja dengan relatif untuk terus memperbaiki diri dalam bidang pekerjaannya. Kompetensi secara emosional membawa individu pelaku usaha untuk relatif stabil dalam beradaptasi dengan perubahan lingkungan kerja, mampu menahan emosi dalam setiap permasalahan pekerjaannya (Sidharta \& Lusiana, 2014).

\section{Peran dan Kebijakan Pemerintah}

UKM atau usaha kecil menengah memiliki kontribusi besar dalam meningkatkan ekonomi daerah dan nasional, karena itu perlu adanya perlindungan secara secara hukum baik undang-undang atau peraturan pemerintah. Adanya kepastian dan perlindungan secara hukum kepada pelaku UKM, baik dalam operasional produksi maupun sisi perbankan, dapat memicu bertumbuhnya UKM, sehingga nantinya dapat memberikan kontribusi peningkatan 
perekonomian nasional Indonesia (Wuryandani, 2013).

Upaya perlindungan hukum dari pemerintah akan memberikan dampak terwujudnya ketertiban umum dalam usaha, dan memberikan kenyamanan kepada pelaku usaha maupun masyarakat luas, sehingga tercapai stabilitas sosial ekonomi (Wuryandani, 2013). Peranan pemerintah untuk berperan aktif dalam mengembangkan UKM diantaranya adalah untuk menumbuhkan potensi UKM, dan kontribusi UKM terhadap pembangunan perekonomian nasional dalam rangka pemerataan pembangunan, memperluas lapangan kerja, dan meningkatkan pendapatan. Sehingga kebijakan pemerintah terhadap para pelaku UKM hendaknya memiliki tujuan secara administratif dan pengaturan usaha, serta memiliki tujuan untuk melakukan pembinaan kepada para pelaku UKM (Wuryandani, 2013).

\section{Kreativitas Strategi Pemasaran}

Menurut Andrews dan Smith (1996), kreativitas strategi pemasaran adalah merupakan kreativitas tindakan untuk memasarkan suatu produk, kreativitas memusatkan pada hal-hal yang baru, dan pengembangan alternatif cara-cara yang lebih baru, karena bisnis sangat dinamis sehingga setiap perubahan langkah, harus selaras sesuai percepatan (Utaminingsih, 2016).

Strategi didasarkan dari upaya perusahaan di dalam mencari dasar-dasar keunggulan dalam bersaing dari strategi generik diantaranya adalah strategi efisiensi kerja untuk menekan biaya produksi yang rendah sehingga dapat menetapkan harga produk yang terjangkau bagi pelanggan. Strategi fokus kepada pelanggan (customer focus) yang mendasarkan pada upaya untuk memenuhi kebutuhan dan keinginan pelanggan serta produk yang memiliki lini produk sedikit sehingga dapat meminimalkan terjadinya perang iklan (Suci, 2009).

Pelaku usaha harus mampu melayani kebutuhan dari segmentasi konsumen tertentu dengan lebih baik. Pelaku usaha dapat membagi pasar dengan segmentasi yang strategis dan dapat merancang strategi pemasaran. Pelaku usaha dapat mengevaluasi dan menentukan prioritas segmen pasar potensial untuk dijadikan sebagai target penjualan (targeting). Pelaku usaha dapat merumuskan produk dalam upaya mempengaruhi persepsi pelanggan, menganggap produk yang berbeda (different), dan menarik sesuai yang diinginkan pelanggan dari pada produk pesaing (Zulkarnaen \& Sutopo, 2013). 
Pelaku usaha dapat menentukan media promosi untuk menyebarkan informasi perihal manfaat produk, mempengaruhi pelanggan dan mengingatkan kepada para pelanggan sasaran agar membeli produk yang ditawarkan (Zulkarnaen \& Sutopo, 2013).

\section{Kinerja UKM}

Menurut hasibuan (2002), kinerja merupakan hasil kerja yang dicapai seseorang atau oleh organisasi atas tugas tanggung jawab yang menjadi beban yang didasarkan pada kecakapan, pengalaman, keseriusan dan waktu (Harahap, 2014). Menurut miner (1992) kinerja digunakan untuk melihat hasil produktifitas kerja baik orientasi produk barang maupun produk jasa. Menurut Welbourne et. al, (1998) dalam Rotundo \& Sackett (2002), kinerja diartikan sebagai kualitas dan banyaknya hasil dari suatu tugas atau pekerjaan. Menurut Ratundo \& Sackett (2002), mengartikan kinerja sebagai suatu tindakan dan perilaku yang dikontrol seseorang di mana memberikan kontribusi pada organisasi usaha (Gusti, Darya, \& Madani, 2012).

\section{Penelitian Yang Relevan}

Beberapa penelitian yang telah dilakukan para peneliti sebelumnya, di beberapa wilayah di Indonesia, diantaranya sebagai berikut:
1) Penelitian Gadiza Krisdanti dan Rodhiyah, menyimpulkan bahwa karakteristik UKM, karakteristik enterpreneur, psikologi dan potensi Sumber Daya Manusia memiliki hubungan dan berpengaruh positif terhadap kinerja UKM. Karakteristik UKM dan SDM memiliki pengaruh yang paling signifikan terhadap kinerja UKM, sedangkan kreativitas dan inovasi tidak berpengaruh terhadap kinerja UKM. Pada penelitian ini disarankan untuk meningkatkan pemasaran, pengalaman usaha dan peluang usaha, konsistensi dalam usaha dan kemampuan menggunakan teknologi (Krisdanti \& Rodhiyah, 2016).

2) Grisna Anggadwita \& Qaanita Yuuha Mustafid (2013) Identification of Factors Influencing the Performance of Small Medium Enterprises. Hasil penelitian, bahwa aspek kewirausahaan dan aspek sumber daya manusia memiliki pengaruh yang besar (Krisdanti \& Rodhiyah, 2016).

3) Musran Munizu (2010), Pengaruh Faktor Eksternal dan Internal Terhadap Kinerja Usaha Mikro dan Kecil di Sulawesi Selatan. Hasil penelitian menunjukkan bahwa faktorfaktor internal dan eksternal berpengaruh signifikan dan positif 
terhadap kinerja usaha mikro dan kecil (Krisdanti \& Rodhiyah, 2016).

4) Moh Fatkhul Mujib (2010), analisis faktor-faktor yang memiliki pengaruh secara langsung dan yang memiliki pengaruh tidak langsung terhadap kinerja usaha kecil dan menengah (UKM) pada studi kasus pelaku UKM di Kebumen. Hasil penelitian menunjukkan bahwa nilai kewirausahaan berpengaruh secara langsung dan berpengaruh secara positif pada kinerja usaha dan tidak berpengaruh secara langsung terhadap kinerja yang melalui variabel intervening strategi (Krisdanti \& Rodhiyah, 2016).

Penelitian ini akan meneliti pengaruh faktor internal dan faktor eksternal terhadap kinerja UKM. Adapun faktor internal yang menjadi variabel penelitian adalah variabel kompetensi pelaku usaha UKM dan kreativitas strategi pemasaran UKM sebagai variabel intervening, sedangkan faktor eksternal yang diteliti adalah peran dan kebijakan pemerintah terhadap UKM. Model paradigma penelitian apabila dibandingkan dengan beberapa model paradigma penelitian terdahulu yang menjadi pembaharu pada model paradigma penelitian ini adalah variabel kompetensi pelaku usaha serta variabel peran dan kebijakan pemerintah yang akan dibuktikan pengaruhnya terhadap kinerja UKM melalui variabel intervening kreativitas strategi pemasaran.

Tujuan dilaksanakannya penelitian adalah:

1) Untuk mencari tahu bagaimana pengaruh kompetensi pelaku usaha terhadap kinerja UKM di kota Tangerang.

2) Untuk mencari tahu bagaimana pengaruh peran dan kebijakan pemerintah kota Tangerang, terhadap kinerja UKM di kota Tangerang.

3) Untuk mencari tahu bagaimana pengaruh kreativitas strategi pemasaran terhadap kinerja UKM di kota Tangerang.

4) Untuk mencari tahu bagaimana pengaruh kompetensi pelaku usaha dalam mendukung keberhasilan kinerja UKM di kota Tangerang melalui variabel kreativitas strategi pemasaran.

5) Untuk mencari tahu bagaimana pengaruh peran dan kebijakan pemerintah dalam mendukung kinerja UKM di kota Tangerang melalui variabel kreativitas strategi pemasaran.

\section{B. Metode Penelitian}

Metode penelitian yang digunakan, menggunakan metode penelitian kuantitatif asosiatif dengan mencari 
hubungan antara variabel, pengambilan data dilakukan dengan teknik survei mengunakan kuesioner yang dibagikan ke responden.

Waktu dan Lokasi Penelitian

Waktu penelitian selama 4 bulan, yaitu di mfulai bulan juni, juli, agustus, dan september 2019. Lokasi penelitian dilakukan pada kelompok Usaha Kecil Menengah (UKM) di kota Tangerang.

\section{Populasi dan Sampel}

Populasi yang dijadikan sebagai responden dalam penelitian adalah para pelaku UKM yang bertempat tinggal dan menjalankan usahanya di kota Tangerang, dengan total sampel yang diambil sebanyak 200 responden.

\section{Teknik Pengumpulan Data}

Data yang digunakan dalam penelitian ini, menggunakan data sekunder dan data primer. Data sekunder diambil dari data statistik BPS kota Tangerang, dan data dari sumber yang terpercaya. Kajian teori penelitian juga diambil dari beberapa referensi dari penelitian terdahulu yang relevan, dari rujukan data elektronik dan dari referensi pustaka. Sedangkan Data primer penelitian menggunakan data yang didapatkan dari data hasil kuesioner.

\section{Teknik Pengambilan Sampel}

Teknik pengambilan sampel menggunakan teknik Nonprobability Sampling dengan kategori Judgmental
Sampling, yaitu hanya pelaku dan pemilik UKM yang masih aktif berdomisili dan menjalankan usahanya di wilayah kota Tangerang.

\section{Kerangka Pemikiran}

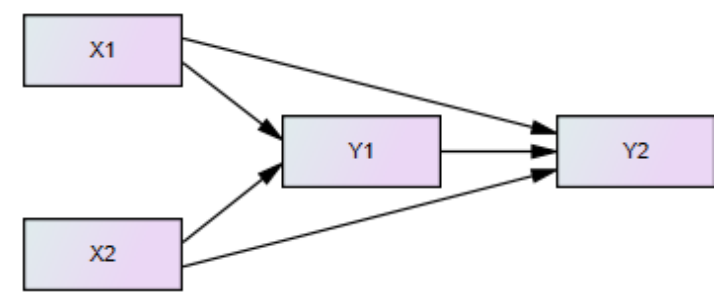

Keterangan:

X1: Kompetensi Pelaku Usaha

X2: Peran dan Kebijakan Pemerintah

Y1: Kreativitas Strategi Pemasaran

Y2: Kinerja UKM

\section{Kisi-kisi instrumen penelitian}

Berdasarkan kajian teori dan data empiris, dihasilkan rumusan kisi-kisi instrumen sebagai berikut:

Tabel kisi-kisi instrumen penelitian

\begin{tabular}{|c|c|c|c|}
\hline No & Variabel & Indikator & Deskripsi \\
\hline \multirow{5}{*}{1} & \multirow{5}{*}{$\begin{array}{l}\text { Kompetensi } \\
\text { Pelaku } \\
\text { Usaha }\end{array}$} & Pengetahuan & Mengetahui cara menyelesaikan tugas kerja \\
\hline & & Ketrampilan & Terampil, cekat dan tepat dalam bekerja. \\
\hline & & Kemampuan & Mampu mengerjakan tugas kerja. \\
\hline & & Sikap/attitude & Memiliki motivasi keja yang relatif stabil \\
\hline & & Bidang keahlian & $\begin{array}{l}\text { Memiliki keahlian kerja pada bidang usaha } \\
\text { yang digeluti. }\end{array}$ \\
\hline \multirow{5}{*}{2} & \multirow{5}{*}{$\begin{array}{l}\text { Peran dan } \\
\text { Kebijakan } \\
\text { Pemerintah }\end{array}$} & $\begin{array}{l}\text { Perlindungan } \\
\text { hukum }\end{array}$ & $\begin{array}{l}\text { Kebijakan pemerintah dalam memberikar } \\
\text { kemudahan perijinan usaha. }\end{array}$ \\
\hline & & $\begin{array}{l}\text { Stabilitas usaha/ } \\
\text { ekonomi }\end{array}$ & $\begin{array}{l}\text { Peran pemerintah dalam mewujudkar } \\
\text { stabilitas perekonomian. }\end{array}$ \\
\hline & & $\begin{array}{l}\text { Peminjaman } \\
\text { modal/perbankan }\end{array}$ & $\begin{array}{l}\text { Peran pemerintah dalam menfasilitas } \\
\text { bantuan pinjaman permodalan usaha. }\end{array}$ \\
\hline & & Pembina an UKM & $\begin{array}{l}\text { Pemerintah terus melakukan pembinaar } \\
\text { kepada pelaku UKM. }\end{array}$ \\
\hline & & $\begin{array}{l}\text { Pengaturan } \\
\text { administrasi }\end{array}$ & $\begin{array}{l}\text { Memberkan kemudahan dalam aturar } \\
\text { kebijakan administrasi UKM. }\end{array}$ \\
\hline \multirow{7}{*}{3} & \multirow{7}{*}{$\begin{array}{l}\text { Kreativitas } \\
\text { Strategi } \\
\text { Pemasaran }\end{array}$} & $\begin{array}{l}\text { Altematif cara- } \\
\text { cara baru }\end{array}$ & $\begin{array}{l}\text { Selalu mencari altematif cara-cara ban } \\
\text { dalam memasarkan produk UKM. }\end{array}$ \\
\hline & & Fokus pelanggan & $\begin{array}{l}\text { Menerapkan strategi fokus memenuh } \\
\text { kebutuhan pelanggan. }\end{array}$ \\
\hline & & Segmentasi & Menetapkan segmen pasar pelanggan. \\
\hline & & Targeting & Menetapkan pronitas target pelanggan \\
\hline & & Positioning & Rumusan persepsi produk ke pelanggan \\
\hline & & $\begin{array}{l}\text { Keterjangkauan } \\
\text { harga }\end{array}$ & $\begin{array}{l}\text { Menetapkan harga produk yang terjangkat } \\
\text { pelanggan. }\end{array}$ \\
\hline & & Promosi & $\begin{array}{l}\text { Agresif dalam menginformasikan produl } \\
\text { kepada pelanggan. }\end{array}$ \\
\hline \multirow{3}{*}{4} & \multirow{3}{*}{$\begin{array}{l}\text { Kinerja } \\
\text { UKM }\end{array}$} & Kuantitashasil & Jumlah hasil dari penyelesaian pekerjaan. \\
\hline & & Kualitas hasil & Kualitas dari hasil penyelesaian pekerjaan \\
\hline & & $\begin{array}{l}\text { Kontribusi } \\
\text { organisasi }\end{array}$ & $\begin{array}{l}\text { Hasil pendapatan yang diterima pelakt } \\
\text { usaha. }\end{array}$ \\
\hline
\end{tabular}




\section{Teknis Analisis Data}

Teknis analisis data yang dipilih adalah statistik inferensial dengan regresi melalui variabel intervening kreativitas strategi pemasaran menggunakan program SPSS 23. Statistik inferensial digunakan untuk menarik kesimpulan dari hubungan antara variabel penelitian sebagai informasi yang bersumber dari data sampel yang berhasil dikumpulkan.

\section{Hasil Penelitian dan Pembahasan}

Berikut output olah data dari program SPSS 23.

\section{Struktural 1:}

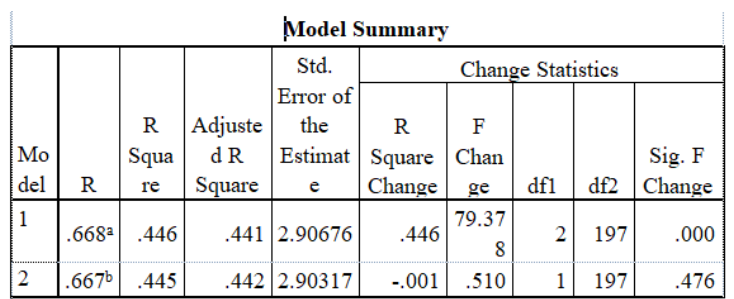
a. Predictors: (Constant), TOTAL_X2, TOTAL_X1 b. Predictors: (Constant), TOTAL_X1

Koefisien determinasi pada model ke-1 $\left(\mathrm{R}^{2}\right)$ senilai 0,446, dan model ke-2 $\left(\mathrm{R}^{2}\right)$ senilai 0,445 . Sehingga nilai error model $2, \varepsilon=1-R^{2}=1-0,445=0,555$.

\begin{tabular}{|c|c|c|c|c|c|c|}
\hline \multicolumn{7}{|c|}{ ANOVA } \\
\hline \multicolumn{2}{|c|}{ Model } & $\begin{array}{l}\text { Sum of } \\
\text { Squares }\end{array}$ & df & $\begin{array}{l}\text { Mean } \\
\text { Square }\end{array}$ & $\mathrm{F}$ & Sig. \\
\hline \multirow[t]{3}{*}{1} & Regression & 1341.367 & 2 & 670.684 & 79.378 & $.000^{\mathrm{b}}$ \\
\hline & Residual & 1664.508 & 197 & 8.449 & & \\
\hline & Total & 3005.875 & 199 & & & \\
\hline \multirow[t]{3}{*}{2} & Regression & 1337.058 & 1 & 1337.058 & 158.638 & $.000^{\circ}$ \\
\hline & Residual & 1668.817 & 198 & 8.428 & & \\
\hline & Total & 3005.875 & 199 & & & \\
\hline \multicolumn{7}{|c|}{ a. Dependent Variable: TOTAL_Y1 } \\
\hline \multicolumn{7}{|c|}{ b. Predictors: (Constant), TOTAL_X2, TOTAL_X1 } \\
\hline \multicolumn{7}{|c|}{ c. Predictors: (Constant), TOTAL_X1 } \\
\hline
\end{tabular}

1) Model 1, $F_{0}=79,378 ;$ df1 $=2$; df2 = 197, $p$-value $=0,000<0,05$ atau $\mathrm{H}_{0}$ ditolak,

2) Model $2, \mathrm{~F}_{0}=158,638 ; \mathrm{df} 1=1 ; \mathrm{df} 2=$ 198, $p$-value $=0,000<0,05$ atau $\mathrm{H}_{0}$ ditolak.

Dengan demikian secara bersamasama/ simultan, baik model ke-1 maupun model ke-2, variabel X1 dan variabel X2 memiliki pengaruh terhadap variabel Y1.

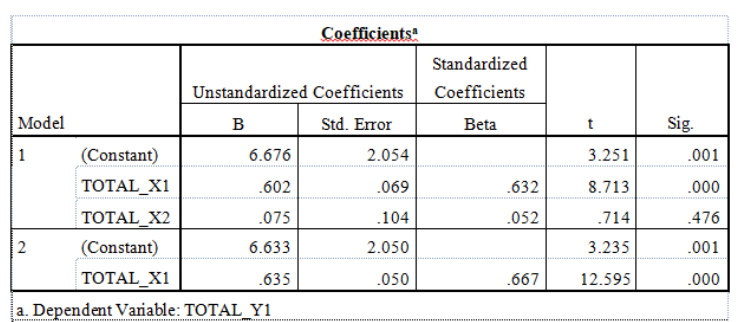

Dengan metode backward didapat dua model hasil pengolahan data, yaitu model ke-1 dan model ke-2. Di mana koefisien jalur ditunjukkan oleh kolom Standardized Coefficients (Beta). Dari tabel Coefficients pada model 1, diperoleh berturut-turut:

1) Koefisien jalur $\mathrm{X} 1$ terhadap $\mathrm{Y} 1\left(\rho_{\mathrm{y} 1 . \mathrm{x} 1}\right)$ $=0,632 ; \mathrm{t}_{0}=8,713$, p-value $=0,000<$ 0,05 atau $\mathrm{H}_{0}$ ditolak, yang berarti terdapat pengaruh variabel $\mathrm{X} 1$ terhadap variabel Y1.

2) Koefisien jalur $\mathrm{X} 2$ terhadap $\mathrm{Y} 1\left(\rho_{\mathrm{y} 1 . \mathrm{x} 2}\right)$ $=0,052 ; \mathrm{t}_{0}=0,714, p$-value $=0,476 / 2$ $=0,238>0,05$ atau $\mathrm{H}_{0}$ diterima, yang berarti tidak terdapat pengaruh variabel $\mathrm{X} 2$ terhadap variabel $\mathrm{Y} 1$.

Struktural 2:

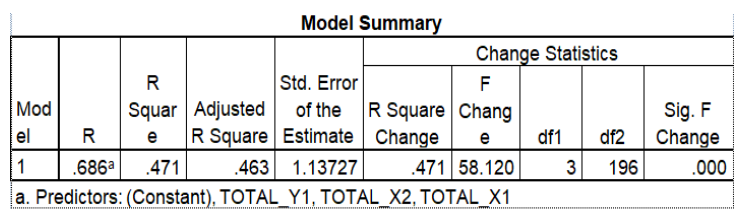


Koefisien determinasi $\left(\mathrm{R}^{2}\right)$ sebesar 0,471, berarti $47,1 \%$ variabilitas variabel $\mathrm{Y} 2$ dapat dijelaskan oleh variabel X1, X2, dan Y1. Sehingga $\varepsilon=1-\mathrm{R}^{2}=1-0,471=$ 0,529 .

\begin{tabular}{|l|r|r|r|r|r|}
\hline \multicolumn{8}{|c|}{ ANOVA $^{\text {Model }}$} & $\begin{array}{c}\text { Sum of } \\
\text { Squares }\end{array}$ & \multicolumn{1}{c|}{$\mathrm{df}$} & $\begin{array}{c}\text { Mean } \\
\text { Square }\end{array}$ & $\mathrm{F}$ & Sig. \\
\hline $1 \quad \begin{array}{l}\text { Regressi } \\
\text { on }\end{array}$ & 225.515 & 3 & 75.172 & 58.120 & $.000^{\mathrm{b}}$ \\
\hline $\begin{array}{l}\text { Residual } \\
\text { Rotal }\end{array}$ & 253.505 & 196 & 1.293 & & \\
\hline Total & 479.020 & 199 & & & \\
\hline
\end{tabular}

a. Dependent Variable: TOTAL_Y2

b. Predictors: (Constant), TOTAL_Y1, TOTAL_X2, TOTAL_X1

Berdasarkan hasil dari tabel di atas, diperoleh bahwa, $\mathrm{F}_{0}=58,120 ; \mathrm{df} 1=3 ; \mathrm{df} 2$ $=196$, p-value $=0,000<0,05$ atau $\mathrm{H}_{0}$ ditolak. Dengan demikian, variabel X1, $\mathrm{X} 2$, dan Y1 secara simultan berpengaruh terhadap kinerja UKM. Adapun pengaruh langsung dapat dipelajari pada output berikut:

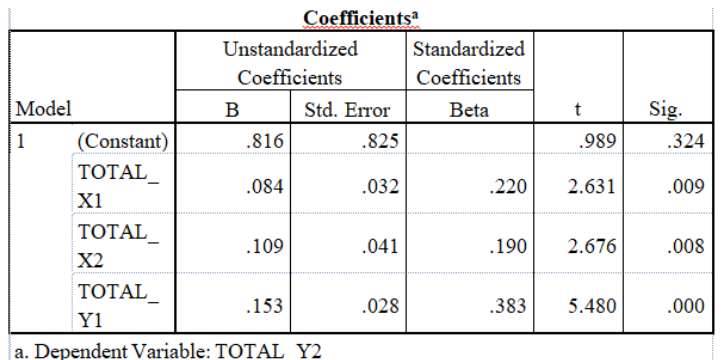

Dengan metode backward, didapat koefisien jalur yang dapat dilihat pada kolom Standardized Coefficients (Beta).

Dari tabel Coefficients, diperoleh:

1) Koefisien jalur $\mathrm{X} 1$ terhadap $\mathrm{Y} 2$ $\left(\rho_{\text {y2.x1 }}\right)=0,220 ; t_{0}=2,631, p$-value $=$ $0,009 / 2=0,0045<0,05, \mathrm{H}_{0}$ ditolak, yang artinya X1 memiliki pengaruh secara langsung dan positif terhadap Y2.

2) Koefisien jalur $X 2$ terhadap $Y 2 \rho_{y 2 . x 2}$ $=0,190 ; \mathrm{t}_{0}=2,676, p$-value $=0,008 / 2$ $=0,004<0,05, \mathrm{H}_{0}$ ditolak, yang artinya X2 memiliki pengaruh langsung positif terhadap Y2.

3) Koefisien jalur Y1 terhadap Y2 $\left(\rho_{\mathrm{y} 2 . \mathrm{y} 1}\right)$ $=0,383 ; \mathrm{t}_{0}=5,480$, -value $=0,000<$ $0,05, \mathrm{H}_{0}$ ditolak, yang artinya $\mathrm{Y} 1$ berpengaruh secara langsung dab positif terhadap Y2.

Tabel ringkasan hasil pengujian hipotesis:

\begin{tabular}{|c|c|c|c|c|c|}
\hline $\begin{array}{l}\text { Pengaruh langsung } \\
\text { antar variabel }\end{array}$ & $\begin{array}{l}\text { Koefisien } \\
\text { Jalur }\end{array}$ & $\begin{array}{c}\text { Kesalahan } \\
\text { baku }\end{array}$ & thitung & $p$-value & Simpulan \\
\hline $\mathrm{X} 1$ terhadap Y2 $\left(\rho_{\mathrm{y} 2 \mathrm{x} 1}\right)$ & 0,220 & 0,032 & 2,631 & 0,0045 & Sig \\
\hline $\mathrm{X} 2$ terhadap $\mathrm{Y} 2\left(\rho_{\mathrm{y} 2 \mathrm{x} 2}\right)$ & 0,190 & 0,041 & 2,676 & 0,004 & Sig \\
\hline Y1 terhadap Y2 ( $\left.\rho_{y 2} . \mathrm{y} 1\right)$ & 0,383 & 0,028 & 5,480 & 0,000 & Sig \\
\hline $\mathrm{X} 1$ terhadap Y1( $(\rho \mathrm{y} 1 . \mathrm{x} 1)$ & 0,632 & 0,069 & 8,713 & 0,000 & Sig \\
\hline $\mathrm{X} 2$ terhadap $\mathrm{Y} 1\left(\rho_{\mathrm{y} 1 . \mathrm{x} 2}\right)$ & 0,052 & 0,104 & 0,714 & 0,238 & Tidak Sig. \\
\hline
\end{tabular}

Dari hasil nilai $\beta$ tersebut di atas dapat digambarkan sebagai berikut:

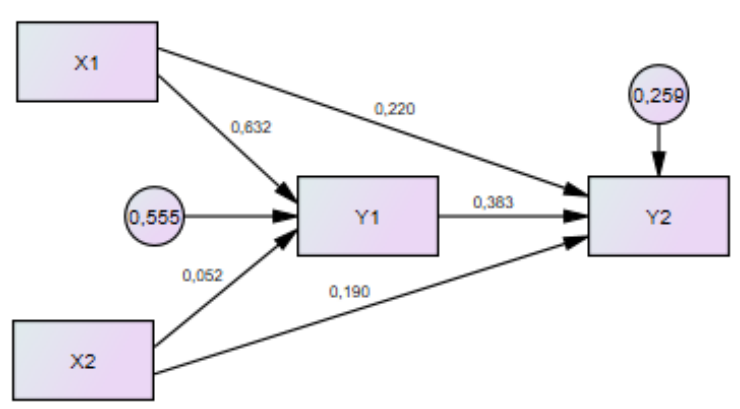

Maka dapat disimpulkan:

1) Besarnya nilai pengaruh langsung $X 1$ terhadap Y2 adalah sebesar $(0,220)^{2}=$ 0,0484 .

2) Besarnya nilai pengaruh variabel $X 1$ terhadap variabel Y2 secara tidak langsung melalui $\mathrm{Y} 1=0,632 \times 0,383$ $=0,2421$. 
3) Besarnya nilai pengaruh total variabel $\mathrm{X} 1$ ke variabel Y2, merupakan hasil penjumlahan pengaruh langsung dengan pengaruh tidak langsung, $0,0484+0,2421=0.2905$.

4) Besarnya nilai pengaruh langsung $X 2$ terhadap Y2 sebesar $(0,190)^{2}=$ 0,0361 .

5) Besarnya nilai pengaruh variabel $X 2$ terhadap variabel Y2 secara tidak langsung melalui Y1 $=0,052 \times 0,383$ $=0,0199$.

6) Besarnya nilai pengaruh total variabel $\mathrm{X} 2$ ke variabel Y2, merupakan hasil penjumlahan dari pengaruh langsung dengan pengaruh tidak langsung, $0,0361+0,0199=0.056$.

\section{Kesimpulan, Implikasi, dan Saran}

\section{Kesimpulan}

Berdasar output olah data dengan SPSS 23 menghasilkan persamaan struktural sebagai berikut:

\section{Persamaan struktural 1:}

$\mathrm{Y}_{1}=0,632 * \mathrm{X}_{1}+0,052 * \mathrm{X}_{2}+0,555$

\section{Persamaan struktural 2:}

$\mathrm{Y}_{2}=0,220 \mathrm{X}_{1}+0,190 \mathrm{X}_{2}+0,383 \mathrm{Y}_{1}+0,259$

Uji hipotesis pada masing-masing pengaruh variabel sebagai berikut:

1) Variabel kreativitas strategi pemasaran memiliki pengaruh yang paling besar terhadap kinerja UKM di kota Tangerang, hal ini ditunjukkan dengan koefisien jalur sebesar 0,383 di mana nilai ini lebih besar dari nilai koefisien jalur peran dan kebijakan pemerintah sebesar 0,190 dan kompetensi pelaku usaha sebesar 0,220. Dapat disimpulkan juga bahwa rata-rata skor kriterium kinerja UKM akan mengalami perubahan 0,383 untuk setiap unit pada kreativitas strategi pemasaran, mengalami perubahan 0,220 untuk setiap unit pada variabel kompetensi pelaku usaha, mengalami perubahan 0,190 untuk setiap unit pada variabel peran dan kebijakan pemerintah perihal UKM.

2) Kompetensi pelaku usaha UKM serta peran dan kebijakan pemerintah perihal UKM, memberikan pengaruh positif secara simultan terhadap kreativitas strategi pemasaran yang diterapkan oleh para pelaku UKM. Hal ini dibuktikan pada nilai statistik output SPSS di mana pada model $1, \mathrm{~F}_{0}$ $=79,378 ; \mathrm{df} 1=2 ; \mathrm{df} 2=197, p$-value $=$ $0,000<0,05$ atau $\mathrm{H}_{0}$ ditolak, dan model $2, \mathrm{~F}_{0}=158,638 ; \mathrm{df} 1=1 ; \mathrm{df} 2=$ 198, -value $=0,000<0,05$ atau $\mathrm{H}_{0}$ ditolak. Artinya semakin kompetensi pelaku usaha baik, serta daya dukung peran dan kebijakan pemerintah perihal UKM yang baik, maka akan berpengaruh terhadap kreativitas strategi pemasaran yang dilakukan 
para pelaku UKM berjalan dengan baik.

3) Kompetensi pelaku usaha UKM berpengaruh positif dan signifikan terhadap kreativitas strategi pemasaran. Hal ini ditunjukkan pada nilai statistik dengan koefisien jalur X1 terhadap Y1 $\left(\rho_{\mathrm{y} 1 . \mathrm{x} 1}\right)=0,632 ; \mathrm{t}_{0}=$ 8,713 , $p$-value $=0,000<0,05$. Artinya semakin pelaku UKM memiliki kompetensi yang baik maka semakin baik pula kreativitas strategi pemasaran yang diterapkan para pelaku UKM.

4) Kebijakan pemerintah perihal UKM tidak memiliki pengaruh secara signifikan terhadap kreativitas strategi pemasarn UKM, hal ini ditunjukkan dengan nilai statistik pada koefisien jalur X2 terhadap Y1 $\left(\rho_{\mathrm{y} 1 . x 2}\right)=0,052$; $\mathrm{t}_{0}=0,714, \quad p$-value $=0,476 / 2=0,238$ $>0,05$.

5) Kompetensi pelaku usaha, peran dan kebijakan pemerintah serta kreativitas strategi pemasaran secara simultan memberikan pengaruh yang positif dan signifikan terhadap kinerja UKM di kota Tangerang, hal ini ditunjukkan dengan nilai statistik $\mathrm{F}_{0}=58,120 ;$ df1 $=3 ; \mathrm{df} 2=196, p$-value $=0,000<0,05$

6) Kompetensi pelaku usaha berpengaruh secara langsung positif secara signifikan terhadap kinerja UKM. Hal ini ditunjukkan dengan nilai statistik pada koefisien jalur $\left(\rho_{\mathrm{y} 2 . \mathrm{x} 1}\right)=0,220 ; \mathrm{t}_{0}=$ 2,631, -value $=0,009 / 2=0,0045<$ 0,05 .

7) Peran dan kebijakan pemerintah berpengaruh secara langsung positif terhadap kinerja UKM di kota Tangerang, hal ini ditunjukkan pada koefisien jalur X2 terhadap Y2 ( $\left.\rho_{\mathrm{y} 2 . \mathrm{x} 2}\right)$ $=0,190 ; \mathrm{t}_{0}=2,676, p$-value $=0,008 / 2$ $=0,004<0,05$.

8) Kreativitas startegi pemasaran yang dilakukan pelaku usaha UKM di kota Tangerang berpengaruh secara langsung positif terhadap kinerja UKM di kota Tangerang, hal ini ditunjukkan pada nilai koefisien jalur Y1 terhadap $\mathrm{Y} 2\left(\rho_{\text {y2.y1 }}\right)=0,383 ; \mathrm{t}_{0}=5,480, p$-value $=0,000<0,05$.

\section{Implikasi}

Hasil penelitian dapat digunakan sebagai pertimbangan para pelaku UKM, kepada pemerintah dan masyarakat di dalam meningkatkan kinerja UKM. Dari hasil penelitian memberikan arahan pertimbangan sebagai berikut:

1) Menerapkan kreativitas strategi pemasaran yang baik, baik dengan terus mencari alternatif cara-cara baru dalam memasarkan produk, fokus kepada pelanggan sesuai kebutuhan dan keinginan pelanggan, menetapkan segmentasi pelanggan yang tepat 
sesuai dengan produk yang dipasarkan, penetapan target pada segmen potensial dan tepat, menetapkan positioning produk yang tepat dalam informasi produk, penetapan harga yang terjangkau pelanggan dan strategis, serta terus agresif dan konsisten dalam menginformasikan fitur dan benefit produk kepada pelanggan.

2) Menjaga dan meningkatkan kompetensi pelaku UKM yang memiliki pengaruh cukup kuat di dalam meningkatkan kinerja UKM. Baik diantaranya peningkatan pengetahuan/ knowledge pelaku usaha maupun para karyawan UKM dalam usaha dan penyelesaian tugas kerja, terampil, cepat dan tepat di dalam menjalankan usahanya, meningkatkan kemampuan dalam menyelesaikan setiap tugas pekerjaannya, bisa menjaga motivasi pantang menyerah untuk terus semangat menjalankan dan menyelesaikan tugas kerja dalam usahanya, meningkatkan keahlian sesuai bidang usaha yang dijalaninya.

\section{Saran}

Berdasar pada hasil penelitian yang telah dilakukan, maka saran-saran yang bisa diberikan untuk meningkatkan kinerja UKM adalah sebagai berikut:
1) Pemerintah kota Tangerang disarankan dapat memberikan kemudahan dalam urusan perijinan pendirian usaha/ perdagangan sebagai upaya perlindungan hukum kepada pelaku UKM.

2) Pemerintah kota Tangerang disarankan dapat menciptakan suasana iklim ekonomi yang stabil sehingga pelaku UKM merasakan kenyamanan dalam menjalankan usahanya dari resiko kondisi ekonomi khususnya di daerah kota Tangerang.

3) Pemerintah kota tangerang disarankan dapat membantu dan menfasilitasi pelaku UKM dalam hal bantuan atau peminjaman modal secara syari'ah sehingga tidak memberatkan pihak pelaku UKM.

4) Pemerintah kota Tangerang hendaknya dapat memberikan arahan, pembinaan dan pengawalan kepada pelaku UKM supaya bisa menjalankan usahanya dengan stabil, meningkat, profit dan memberikan impact kepada kenaikan kesejahteraan masyarakat dan ekonomi daerah.

5) Pemerintah memberikan prioritas kemudahan dalam hal urusan administrasi, seperti retribusi, pajak usaha, dan sebagainya. 


\section{E. DAFTAR PUSTAKA}

Gusti, I., Darya, P., \& Madani, S. (2012). Pengaruh Ketidakpastian Lingkungan dan Karakteristik Kewirausahaan Terhadap Kompetensi Usaha dan Kinerja Usaha Mikro Kecil di Kota Balikpapan. In Jurnal Inovasi dan Kewirausahaan (Vol. 1).

Hadiwidjaja, R. D., \& Hartati, N. (2013). Tinjauan Umum Usaha Mikro Kecil dan Menengah Di Indonesia: Permasalahan dan Strategi. Retrieved from www.depkop.go.id

Harahap, Y. R. (2014). Kemampuan Menyusun Laporan Keuangan Yang Dimiliki Pelaku Ukm Dan Pengaruhnya Terhadap Kinerja Ukm. In Jurnal Riset Akuntansi Dan Bisnis.

Irfan, A. (2017). Jumlah UKM Kota Tangerang Alami Peningkatan - ANTARA News Banten. Retrieved from Antara News website:

https://banten.antaranews.com/berita/25907 /jumlah-ukm-kota-tangerang-alamipeningkatan

Krisdanti, G., \& Rodhiyah. (2016). Analisis Faktor-Faktor Yang Mempengaruhi Kinerja UKM Pada Sektor Industri Pengolahan Makanan Di Kota Semarang.

Pemkot. (2017). UMKM di Kota Tangerang Tembus 11 Ribu - Pemerintah Kota Tangerang. Retrieved from https://tangerangkota.go.id/umkm-di-kotatangerang-tembus-11-ribu

Purwidianti, W., \& Rahayu, T. S. M. (2015). Pengaruh Faktor Internal Dan Eksternal Terhadap Kinerja Usaha Industri Kecil Dan Menengah Di Purwokerto Utara.

Setiawan, Z. A. (2018). 60 persen produk Usaha Kecil Menengah di Tangerang Selatan Didominasi Kuliner - Warta Kota. Retrieved from WartaKotalive.com website: http://wartakota.tribunnews.com/2018/09/0 5/60-persen-produk-usaha-kecil-menengahdi-tangerang-selatan-didominasi-kuliner
Sidharta, I., \& Lusiana, D. (2014). Analisis Faktor Penentu Kompetensi Berdasarkan Konsep Knowledge, Skill, Dan Ability (KSA) Di Sentra Kaos Suci Bandung. In Jurnal Computech \& Bisnis (Vol. 8). Retrieved from http://jurnal.stmikmi.ac.id/index.php/jcb/article/view/111

Suci, R. P. (2009). Peningkatan Kinerja Melalui Orientasi Kewirausahaan, Kemampuan Manajemen, dan Strategi Bisnis (Studi pada Industri Kecil Menengah Bordir di Jawa Timur). Jurnal Manajemen Dan Kewirausahaan, 11(1), 46-58. https://doi.org/10.9744/jmk.11.1.pp. 46-58

Susila, A. R. (2017). Upaya Pengembangan Usaha Mikro Kecil dan Menengah dalam Menghadapi Pasar Regional Dan Global.

Syarif, M. (2017). Jumlah UKM Kota Tangerang Alami Peningkatan. Retrieved from Harian Ekonomi Neraca website: http://www.neraca.co.id/article/83183/juml ah-ukm-kota-tangerang-alami-peningkatan

Wuryandani, D. (2013). Peranan kebijakan pemerintah daerah dalam pengembangan usaha mikro, kecil dan menengah di Provinsi Daerah Istimewa Yogyakarta. Jurnal Ekonomi Dan Kebijakan Publik, 4(1), 103-115. Retrieved from http://jurnal.dpr.go.id/index.php/ekp/article /view/71

Zulkarnaen, H. O., \& Sutopo, S. (2013). Analisis Strategi Pemasaran Pada Usaha Kecil Menengah (UKM) Makanan Ringan ( Studi Penelitian UKM Snack Barokah di Solo ). Diponegoro Journal of Management. 